\title{
Relationship between Body Mass Index and Skinfold Thickness in Exercised and Sedentary Boys and Girls
}

\author{
Kenan Sivrikaya ${ }^{1, *}$, Mehmet Akif Ziyagil ${ }^{2}$, Mehmet Çebi ${ }^{3}$ \\ ${ }^{1}$ Faculty of Sport Science, Istanbul Aydın University, Turkey \\ ${ }^{2}$ School of Physical Education and Sports, Mersin University, Turkey \\ ${ }^{3}$ Yaşar Doğu Faculty of Sport Science, Ondokuz Mayıs University, Turkey
}

Copyright $\bigcirc 2019$ by authors, all rights reserved. Authors agree that this article remains permanently open access under the terms of the Creative Commons Attribution License 4.0 International License

\begin{abstract}
This study aimed to determine the prevalence of obesity and the level of association between body mass index (BMI) and total skinfold thickness (TST) in physically active (PA) and sedentary boys and girls aged between 8-14 years. This relationship was tested by Spearman rank order correlation. In both genders, the lower obesity tendency between the ages of 8 and 11 years reached the highest level at the age of 12 years. In sedentary boys, the relationship between BMI and TST at 9 and 11 years old was at the highest level whereas it was the lowest level at 12 and 14 years old. In PA boys, there was a high-level relationship between BMI and TST at 9 and 10 years, and this relationship was the lowest at 12 and 14 years. In PA girls, the relationship between BMI and TST of 9,10 , and 11 years was at the highest and was the lowest at 12 and 13 years. In sedentary girls, the relationship between BMI and TST from 8 to 14 years tends to increase slightly. In conclusion, BMI and TST measurements cannot be used alternately in the evaluation of body composition of inactive and sedentary children aged 8-14 years.
\end{abstract}

Keywords BMI, Total Skinfolds Thickness, Obesity, Children

\section{Introduction}

Overweight and obesity are defined as instant fat accumulation. Results of a study indicate that in 2014, 41 million children under the age of 5 are adversely affected by excessive pounds and obesity [1]. The body mass index (BMI) is a simple index that shows the body weight that is appropriate for the body height used in adults to determine overweight and obesity. The body weight of a person is divided by the square of body height in meters $(\mathrm{kg} / \mathrm{m} 2)$. BMI indicates the nutritional status associated with body fat mass, obesity-induced metabolic and cardiovascular complications [2-3].
Considering the limitations of cross-sectional research design, it has been shown that total skinfold thickness does not provide a more accurate assessment of metabolic risk than BMI [4].

BMI shows a steady increase up to a year after birth, then gradually declines and reaches a minimum level in 5-6 years and finally continues to increase in the rest of the childhood. The point that BMI reaches to the minimal level is the beginning of the fatness that corresponds to the increase in the number of fat tissues. Nevertheless, in some studies, it is reported that BMI changes may not accurately reflect changes of increasing body fatness. Nevertheless, it was reported that BMI changes may not accurately reflect changes of increasing body fatness [5-6]. It was also reported that although the BMI is not a true indicator of body fat mass, [7] changes in BMI reflect changes in the size and number of body fat tissue [8]. In addition to their health-related applications, the total thickness of BMI and skinfolds is associated with a low level of physical fitness, as demonstrated by studies of young people. Comparisons between different BMI groups have shown that those with low and normal BMI values have a higher level of physical fitness than overweight and obese with high BMI [9-10].

Although it is possible to determine the peak height growth rate, body weight, height, skinfold thickness in the evaluation of growth, the most commonly used somatic variable peak height velocity is the age of the growth and maturation studies [11]. With maturation, anthropometric measurements exhibit linear increases, but no change in body composition is observed [12].Generally BMI classifies people associated with body fat mass as under-weight, normal, over-weight and obese, is a cheaper and easier to use as a method than the method of measuring subcutaneous fat thickness [13].

Several researches reported that there are many factors affecting BMI and TST including age, gender, maturity, level of physical activity and genetic characteristics in children of different societies [14-15]. Still there is a question whether BMI and TST can be interchangeably used to estimate body fat as a part of evaluating health 
status in 8-14 years old Turkish children depending on their physical activity levels.

Thus, this study aimed to analyze the relationship among overweight and obesity prevalence, BMI and TST in 8-14 years old boys and girls with respect to their physical activity levels.

\section{Materials and Methods}

Sampling: Accepted the minimum sample size is 381 participants determined by the $5 \%$ margin of error in the $95 \%$ confidence interval required to represent 32000 boys and girls in the city center for this cross-sectional study [16]. Data were collected from a total of 684 children consisting of 389 boys and 295 girls from primary and secondary schools in the city center in Turkey.

Participants: Exercised boys and girls from 8, 9, 10, 11, 12,13 and 14 years participated in regular sportive and physical activity at least three days in a week throughout the year. Sedentary students did not engage in exercise and sport.

Body height and weight measurements: Participants were wearing shorts and t-shirts with bare foot. The body height of the participants was measured by a metal scale with a $0.1 \mathrm{~cm}$ sensitivity, and the body weight measurement was taken by a digital weight with a $0.1 \mathrm{~kg}$ sensitivity.

Body mass index: BMI was calculated by dividing the participant's weight in kilograms by the square of his/her height in meters $\left(\mathrm{kg} / \mathrm{m}^{2}\right)$. In each age group, the body composition were classified as obese for 95 percentiles $\geq$, as overweight for 85 to $<95$ percentiles, as normal weight for 5 to $<85$ and as underweight for $<5$ percentiles [17].
Skinfold measurement: Measurements were taken by Holtain Caliper $(10 \mathrm{~g} / \mathrm{sq} \mathrm{mm})$ from the right side of the body while participants were standing in upright position. Pulling subcutaneous fat layer by holding with the thumb and index finger in the measurement of skinfold thickness was read in muscle tissue gently pulled up enough to be separated from the index finger on the caliper thickness of skinfold calipers placed about $1 \mathrm{~cm}$ apart held for 2-3 seconds. Sum of subscapula, triceps, biceps, suprailiac and abdominal skinfolds were used as TST to evaluate body fatness [18].

Statistical analyses: Data are presented as mean and standard deviation $(\mathrm{X} \pm \mathrm{SD})$. The frequency test was used in order to determine the prevalence of obesity in all age groups between exercised and sedentary boys and girls. Spearman rank order correlation coefficients were calculated between BMI and TST variables due to not normally distributed data.

\section{Results}

The physical characteristics of boys and girls according to age groups are presented in Table 1. The Spearman rank correlation coefficients between the body mass index and the total of 5 skinfolds of boys and girls in different age groups are shown in Table 2. In addition, the Spearman rank correlation coefficients between body mass index and total skinfold thickness variances by age groups of boys and girls are shown in Graphs 1 and 2. In both boys and girls, the tendency to decrease in obesity rates between the ages of 8 and 11 reaches the highest level at 12 years of age and shows an upward trend only in girls after 13 years of age.

Table 1. Distribution of body mass index groups of males and females by age groups

\begin{tabular}{|c|c|c|c|c|c|c|}
\hline \multirow{3}{*}{$\begin{array}{c}\text { Age } \\
\text { Group }\end{array}$} & & \multicolumn{4}{|c|}{ Frequency and Percentages of Body Mass Index Groups } & \multirow{2}{*}{ Total } \\
\hline & & Under-weight & Normal & Over-weight & Obese & \\
\hline & Gender & f - \% & f - \% & f - \% & f - \% & f - \% \\
\hline \multirow{2}{*}{8 Years } & Boys & $2(\% 3,8)$ & $34(\% 65,4)$ & $6(\% 11,5)$ & $10(\% 19,2)$ & $52(\% 100,0)$ \\
\hline & Girls & $1(\% 2,9)$ & $29(\% 85,3)$ & $2(\% 5,9)$ & $2(\% 5,9)$ & $34(\% 100)$ \\
\hline \multirow{2}{*}{9 Years } & Boys & $2(\% 4,3)$ & $33(\% 70,2)$ & $5(\% 10,6)$ & $7(\% 14,9)$ & $47(\% 100)$ \\
\hline & Girls & $4(\% 9,8)$ & $32(\% 78,0)$ & $3(\% 7,3)$ & $2(\% 4,9)$ & $41(\% 100)$ \\
\hline \multirow{2}{*}{10 Years } & Boys & $4(\% 6,8)$ & $41(\% 69,5)$ & $8(\% 13,6)$ & $6(\% 10,2)$ & $59(\% 100)$ \\
\hline & Girls & $7(\% 16,3)$ & $31(\% 72,1)$ & $3(\% 7,0)$ & $2(\% 4,7)$ & $43(\% 100)$ \\
\hline \multirow{2}{*}{11 Years } & Boys & $1(\% 2,5)$ & $28(\% 70,0)$ & $7(\% 17,5)$ & $4(\% 10,0)$ & $40(\% 100)$ \\
\hline & Girls & $3(\% 9,1)$ & $27(\% 81,8)$ & $2(\% 6,1)$ & $1(\% 3,0)$ & $33(\% 100)$ \\
\hline \multirow{2}{*}{12 Years } & Boys & $1(\% 1,7)$ & $33(\% 56,9)$ & $14(\% 24,1)$ & $10(\% 17,2)$ & $58(\% 100)$ \\
\hline & Girls & $6(\% 12,8)$ & $32(\% 68,1)$ & $5(\% 10,6)$ & $4(\% 8,5)$ & $47(\% 100)$ \\
\hline \multirow{2}{*}{13 Years } & Boys & $4(\% 5,3)$ & $52(\% 68,4)$ & $15(\% 19,7)$ & $5(\% 6,6)$ & $76(\% 100)$ \\
\hline & Girls & $6(\% 12,5)$ & $34(\% 70,8)$ & $7(\% 14,6)$ & $1(\% 2,1)$ & $48(\% 100)$ \\
\hline \multirow{2}{*}{14 Years } & Boys & $4(\% 7,0)$ & $41(\% 71,9)$ & $9(\% 15,8)$ & $3(\% 5,3)$ & $57(\% 100)$ \\
\hline & Girls & $2(\% 4,1)$ & $34(\% 69,4)$ & $9(\% 18,4)$ & $4(\% 8,2)$ & $49(\% 100)$ \\
\hline
\end{tabular}


Table 2. Physical characteristics of males and females by age groups

\begin{tabular}{|c|c|c|c|c|c|c|c|c|c|c|}
\hline \multirow{3}{*}{ Variables } & \multirow{3}{*}{ Gender } & \multirow{3}{*}{ Group } & \multicolumn{8}{|c|}{ Age Groups } \\
\hline & & & \multicolumn{2}{|r|}{8 Years } & \multicolumn{2}{|r|}{9 Years } & \multicolumn{2}{|r|}{10 Years } & \multicolumn{2}{|r|}{11 Years } \\
\hline & & & $\mathbf{N}$ & $\mathbf{M} \pm \mathbf{S D}$ & $\mathbf{N}$ & $\mathbf{M} \pm \mathbf{S D}$ & $\mathbf{N}$ & $\mathbf{M} \pm \mathbf{S D}$ & $\mathbf{N}$ & $\mathbf{M} \pm \mathbf{S D}$ \\
\hline \multirow{4}{*}{$\begin{array}{c}\text { Body } \\
\text { Height }(\mathrm{cm})\end{array}$} & \multirow{2}{*}{ Boys } & Sedanter & 47 & $129,15 \pm 5,01$ & 40 & $133,93 \pm 4,79$ & 25 & $138,40 \pm 6,53$ & 27 & $144,41 \pm 6,93$ \\
\hline & & Active & 5 & $128,60 \pm 2,07$ & 7 & $138,71 \pm 8,14$ & 34 & $141,82 \pm 5,62$ & 13 & $146,31 \pm 6,60$ \\
\hline & \multirow{2}{*}{ Girls } & Sedanter & 31 & $129,10 \pm 4,74$ & 34 & $133,88 \pm 5,67$ & 23 & $139,09 \pm 6,01$ & 24 & $144,46 \pm 7,14$ \\
\hline & & Active & 3 & $128,33 \pm 2,08$ & 7 & $134,71 \pm 6,63$ & 20 & $142,20 \pm 5,92$ & 9 & $146,28 \pm 6,20$ \\
\hline \multirow{4}{*}{ Body weight (kg) } & \multirow{2}{*}{ Boys } & Sedanter & 47 & $28,71 \pm 6,46$ & 40 & $30,73 \pm 5,40$ & 25 & $32,77 \pm 6,65$ & 27 & $36,26 \pm 7,41$ \\
\hline & & Active & 5 & $27,00 \pm 4,12$ & 7 & $34,29 \pm 10,63$ & 34 & $36,33 \pm 8,60$ & 13 & $40,81 \pm 9,67$ \\
\hline & \multirow{2}{*}{ Girls } & Sedanter & 31 & $26,63 \pm 4,03$ & 34 & $28,35 \pm 5,39$ & 23 & $31,22 \pm 8,20$ & 24 & $38,67 \pm 9,68$ \\
\hline & & Active & 3 & $28,00 \pm 6,08$ & 7 & $30,00 \pm 6,45$ & 20 & $34,95 \pm 8,06$ & 9 & $40,31 \pm 6,05$ \\
\hline \multirow{4}{*}{$\begin{array}{c}\text { Body Mass Index } \\
\qquad\left(\mathrm{kg} / \mathrm{m}^{2}\right)\end{array}$} & \multirow{2}{*}{ Boys } & Sedanter & 47 & $17,25 \pm 3,14$ & 40 & $17,22 \pm 2,39$ & 25 & $17,12 \pm 2,54$ & 27 & $18,46 \pm 3,20$ \\
\hline & & Active & 5 & $16,46 \pm 2,71$ & 7 & $17,83 \pm 4,91$ & 34 & $18,03 \pm 3,29$ & 13 & $18,98 \pm 2,62$ \\
\hline & \multirow{2}{*}{ Girls } & Sedanter & 31 & $16,06 \pm 1,91$ & 34 & $15,89 \pm 2,34$ & 23 & $16,09 \pm 2,92$ & 24 & $17,35 \pm 2,34$ \\
\hline & & Active & 3 & $17,10 \pm 3,36$ & 7 & $16,54 \pm 2,49$ & 20 & $17,30 \pm 3,20$ & 9 & $19,10 \pm 3,64$ \\
\hline \multirow{4}{*}{$\begin{array}{l}\text { Total Skinfold } \\
\text { Thickness (mm) }\end{array}$} & \multirow{2}{*}{ Boys } & Sedanter & 47 & $38,96 \pm 21,38$ & 40 & $41,62 \pm 22,75$ & 25 & $39,06 \pm 18,24$ & 27 & $53,22 \pm 24,85$ \\
\hline & & Active & 5 & $40,92 \pm 32,72$ & 7 & $46,27 \pm 29,94$ & 34 & $49,77 \pm 23,42$ & 13 & $62,52 \pm 30,02$ \\
\hline & \multirow{2}{*}{ Girls } & Sedanter & 31 & $46,74 \pm 20,47$ & 34 & $46,14 \pm 20,48$ & 23 & $45,17 \pm 24,22$ & 24 & $51,98 \pm 19,31$ \\
\hline & & Active & 3 & $51,13 \pm 25,65$ & 7 & $42,70 \pm 16,98$ & 20 & $50,67 \pm 22,67$ & 9 & $60,60 \pm 23,50$ \\
\hline
\end{tabular}

$\mathbf{M}=$ Mean, $\mathbf{S D}=$ Standard Deviation of Mean.

Table 2 continued

\begin{tabular}{|c|c|c|c|c|c|c|c|c|}
\hline \multirow{2}{*}{ Variables } & \multirow{2}{*}{ Gender } & \multirow{2}{*}{ Group } & \multicolumn{2}{|c|}{12 Years } & \multicolumn{2}{|c|}{13 Years } & \multicolumn{2}{|c|}{14 Years } \\
\hline & & & $\mathbf{N}$ & $\mathbf{M} \pm \mathbf{S D}$ & $\mathbf{N}$ & $\mathbf{M} \pm \mathbf{S D}$ & $\mathbf{N}$ & $\mathbf{M} \pm \mathbf{S D}$ \\
\hline \multirow{4}{*}{$\begin{array}{c}\text { Body } \\
\text { Height (cm) }\end{array}$} & \multirow{2}{*}{ Boys } & Sedanter & 31 & $151,35 \pm 6,28$ & 39 & $154,69 \pm 8,14$ & 17 & $163,42 \pm 7,85$ \\
\hline & & Active & 27 & $149,85 \pm 11,5$ & 37 & $160,18 \pm 8,72$ & 40 & $163,54 \pm 10,39$ \\
\hline & \multirow{2}{*}{ Girls } & Sedanter & 33 & $152,53 \pm 8,10$ & 24 & $153,70 \pm 7,37$ & 23 & $159,17 \pm 7,35$ \\
\hline & & Active & 14 & $149,71 \pm 7,81$ & 24 & $157,08 \pm 7,87$ & 26 & $160,46 \pm 6,00$ \\
\hline \multirow{4}{*}{$\begin{array}{c}\text { Body weight } \\
\text { (kg) }\end{array}$} & \multirow{2}{*}{ Boys } & Sedanter & 31 & $46,56 \pm 12,65$ & 39 & $46,95 \pm 9,34$ & 17 & $54,88 \pm 11,85$ \\
\hline & & Active & 27 & $46,46 \pm 8,88$ & 37 & $51,27 \pm 12,90$ & 40 & $53,00 \pm 11,72$ \\
\hline & \multirow{2}{*}{ Girls } & Sedanter & 33 & $42,46 \pm 9,64$ & 24 & $45,81 \pm 9,24$ & 23 & $50,52 \pm 9,88$ \\
\hline & & Active & 14 & $44,86 \pm 10,83$ & 24 & $47,20 \pm 6,33$ & 26 & $54,34 \pm 10,80$ \\
\hline \multirow{4}{*}{$\begin{array}{c}\text { Body Mass } \\
\text { Index }\left(\mathrm{kg} / \mathrm{m}^{2}\right)\end{array}$} & \multirow{2}{*}{ Boys } & Sedanter & 31 & $20,25 \pm 4,28$ & 39 & $19,67 \pm 3,04$ & 17 & $20,59 \pm 3,57$ \\
\hline & & Active & 27 & $20,89 \pm 3,42$ & 37 & $19,94 \pm 3,77$ & 40 & $19,81 \pm 3,24$ \\
\hline & \multirow{2}{*}{ Girls } & Sedanter & 33 & $18,25 \pm 3,18$ & 24 & $19,46 \pm 3,24$ & 23 & $20,05 \pm 3,57$ \\
\hline & & Active & 14 & $20,17 \pm 4,69$ & 24 & $19,30 \pm 2,62$ & 26 & $21,17 \pm 3,66$ \\
\hline \multirow{4}{*}{$\begin{array}{c}\text { Total Skinfold } \\
\text { Thickness } \\
(\mathrm{mm})\end{array}$} & \multirow{2}{*}{ Boys } & Sedanter & 31 & $52,49 \pm 25,43$ & 39 & $49,46 \pm 21,48$ & 17 & $57,85 \pm 24,87$ \\
\hline & & Active & 27 & $59,65 \pm 22,01$ & 37 & $62,08 \pm 33,16$ & 40 & $54,77 \pm 28,23$ \\
\hline & \multirow{2}{*}{ Girls } & Sedanter & 33 & $55,30 \pm 24,85$ & 24 & $56,17 \pm 24,04$ & 23 & $66,43 \pm 27,10$ \\
\hline & & Active & 14 & $59,31 \pm 29,32$ & 24 & $70,66 \pm 23,67$ & 26 & $74,85 \pm 24,35$ \\
\hline
\end{tabular}

$\mathbf{M}=$ Mean, $\mathbf{S D}=$ Standard Deviation of Mean. 


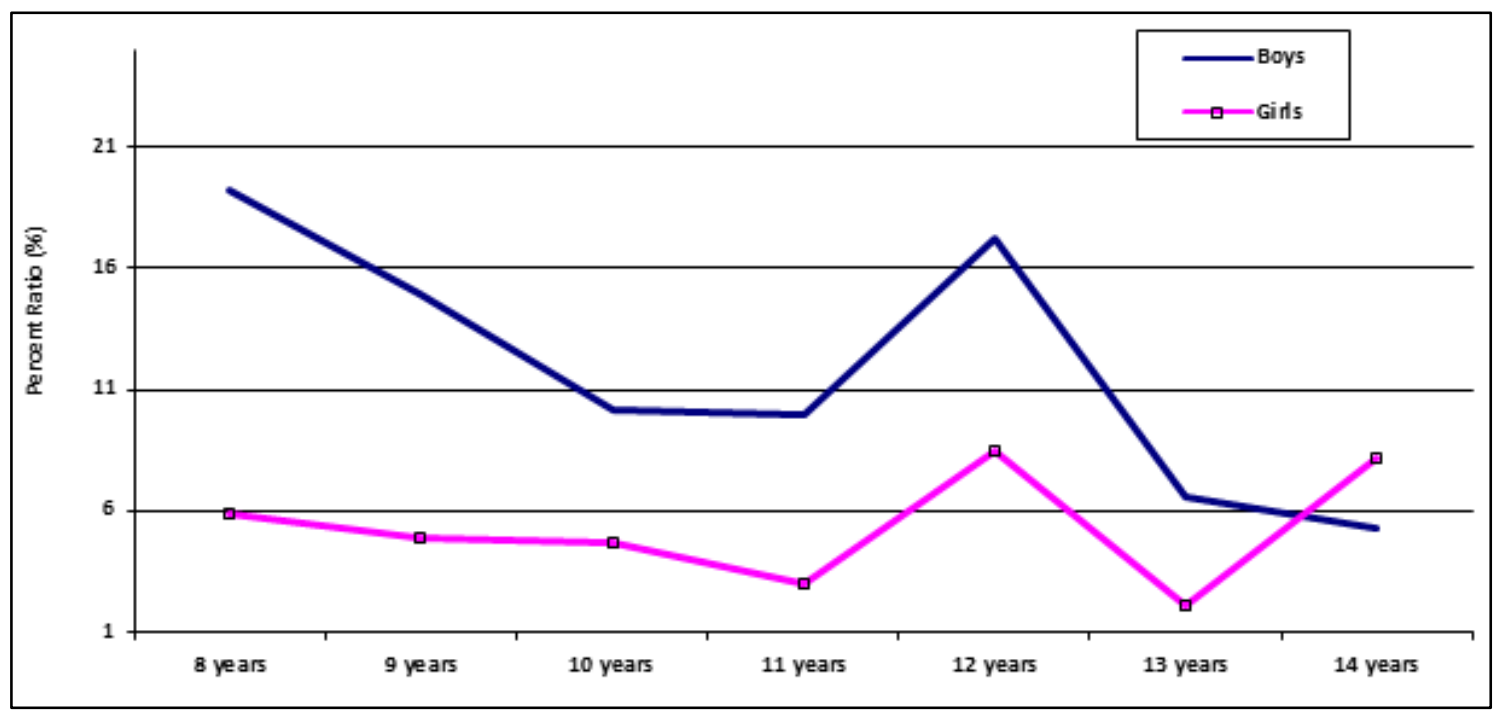

Graph 1. Comparison of obesity levels (\%) between boys and girls according to age groups

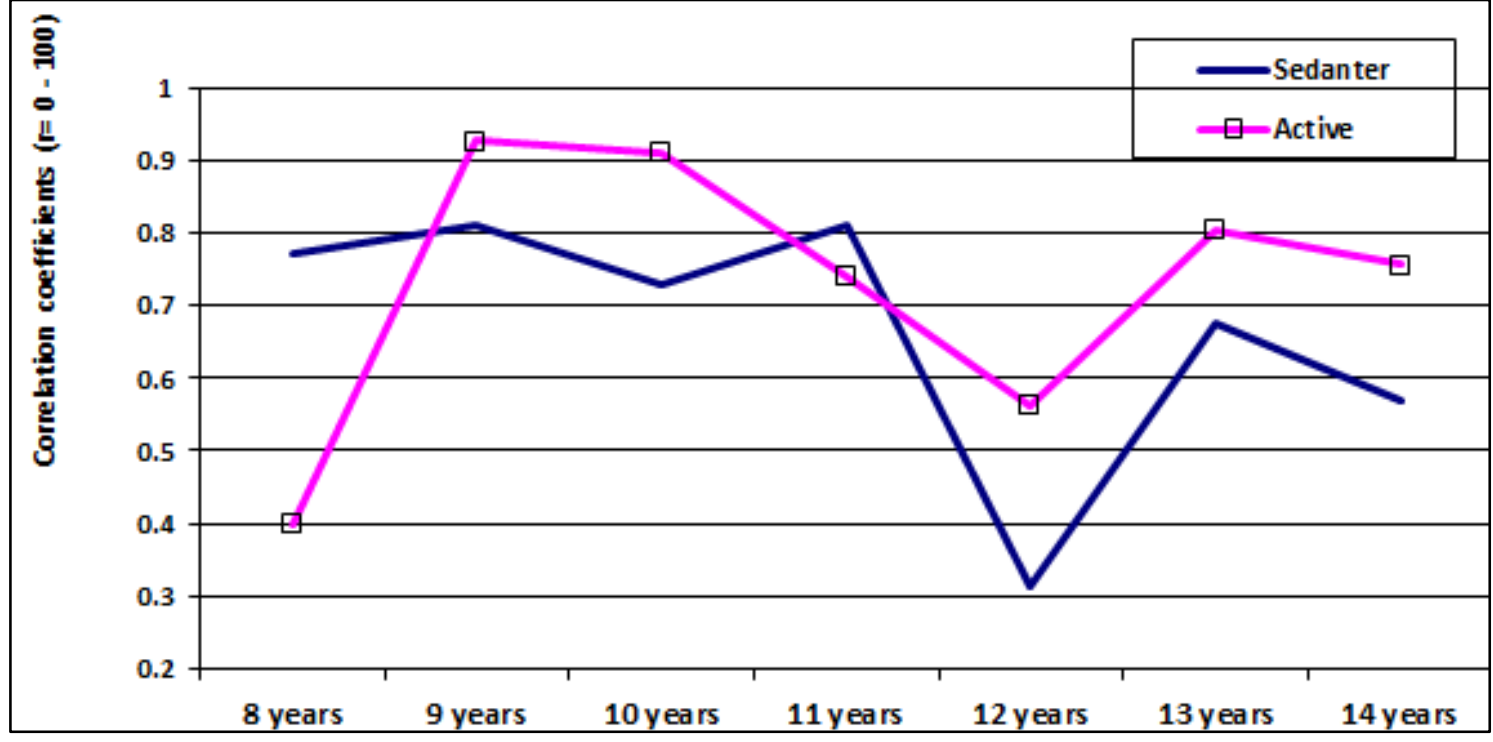

Graph 2. Spearman rank order correlation coefficients between BMI and TST values according to physical activity levels in boys.

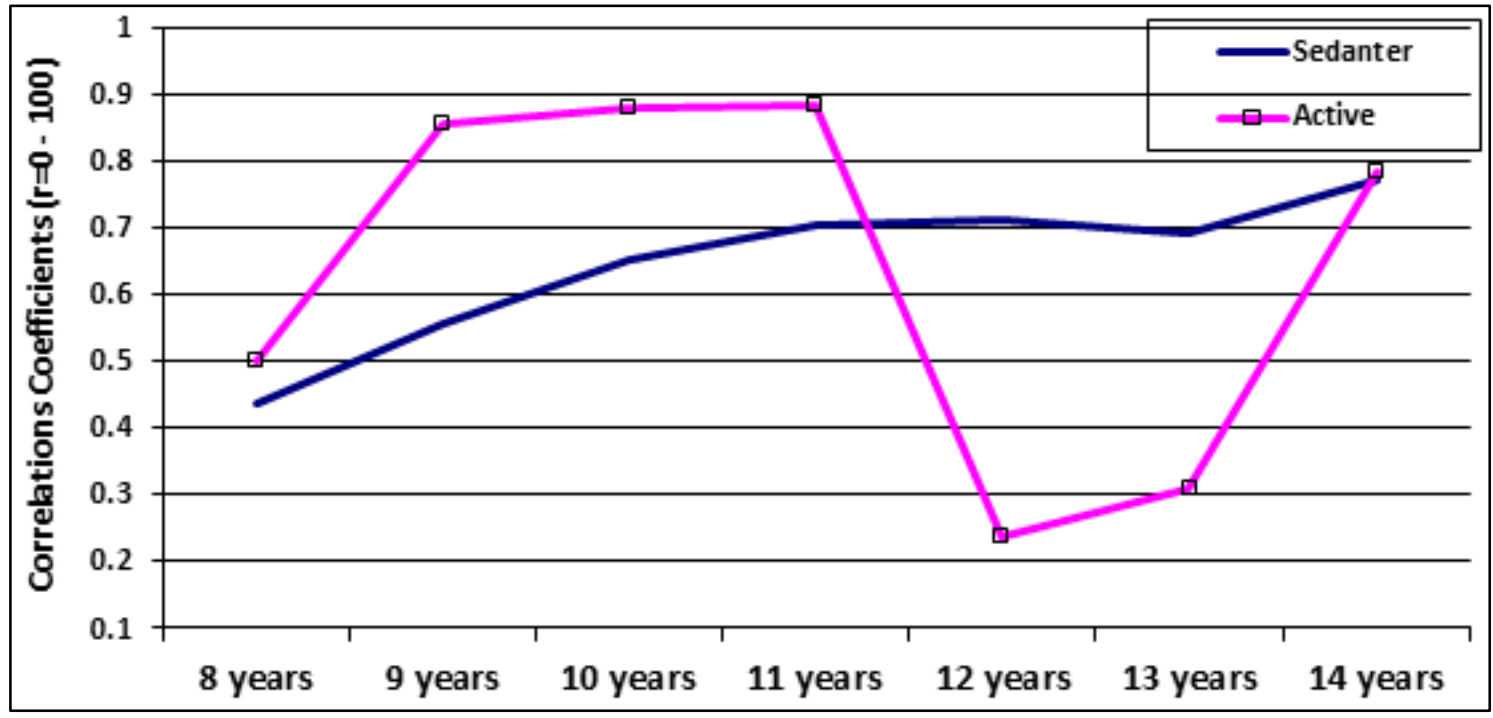

Graph 3. Comparison of Spearman rank order correlation coefficients between BMI and TST values in girls. 


\section{Discussion}

Nowadays, the concept of obesity only shows an increase in total body fat mass, which can be determined by body composition analysis. In terms of assessing the health of children, it is necessary to determine how useful BMI is as a marker of body fat mass. The proportion of body fat in total body mass varies mostly due to age, gender, maturity and genetic characteristics [19]. In this study, it is aimed to determine the relationship between BMI and subcutaneous fat thickness values used in the evaluation of body fat ratio of boys and girls in different age groups. The obesity rate of boys was higher than girls until 14 years old. In boys, the highest obesity rate at the age of 8 years tends to decrease at 9,10 and 11 years of age. Again, the high obesity rate at 12 years tends to decrease by 14 years. In girls, there was slightly a decreasing tendency of obesity from 8 to 11 years while this tendency was highest at 12 years and lowest at the age of 13 years. There was a significant increase in obesity in girls at the age of 14 years (Tables 1 and 2, Graphs 1 and 2).

Despite the similarities between boys and girls in terms of body height and weight, the sexual dimorphism is the best way to explain the gender related differences. Sexual dimorphism explains the differences in the size and shape of the body between boys and girls. This means that males had a larger body structure than females. Adult male is $7 \%$ taller than females [20]. Although differences in body measurements between men and women emerge during the first trimester of pregnancy [21], structural differences mainly appear during the adolescence period. Because the gender related differences were low until the beginning of puberty [22].

For boys participating in regular physical and sport activities, there was a high level correlation between BMI and TST in the ages of 9,10 and 13 years while decreased correlations were observed at the ages of 8 and 12 years. In sedentary boys, there was a high-level correlation between BMI and TST at the ages of $8,9,10$, and 11 years, while the level of correlation between BMI and TST was low at 12 and 14 years of age and was medium at 13 years. There was a high level correlation at the ages of $9,10,11$ and 13 years between the BMI and TST in girls participating in regular physical and sports activities while a low level correlation was observed at 12 and 13 years of age in the physically active group. In sedentary girls, there was an increasing tendency from the low level to moderate correlations from the age of 8 years to 14 years between BMI and TST. In sedentary children, the relationships between BMI and TST were increasing with the increasing age.

The lower level correlations between BMI and TST values were observed in both exercised and sedentary boys at the age of 12 while there was an only lower level correlation in exercised girls. The rapid increase in body height due to peak height velocity may lower the BMI value. So, the relationships between BMI and TST may lower too. It can be evaluated that the correlation between BMI and TST in each age group can be affected by height. Progression of maturation and anthropometric variables continue to grow linearly observed in each PER layer, and this tendency is the result that is not observed in body composition [12].

The linear tendency in peak height velocity period was not observed in the body composition. The mean body fat percent was decreased when the individual's peak height velocity was approached. The results of this study may well explain the declining correlation between BMI and TST with increased mean body height in exercised and sedentary boys and girls.

Although BMI explains the most of information related to metabolic risk factors about obesity, the limitations of the skinfolds measurements should also be considered in the evaluating findings of our study. There was an also significant difference in the measurements of skinfold thickness depending on measurement errors with increasing the body fat level [23, 24].

Skinfold thickness showed a stronger relationship with body fatness compared to the BMI. Although overall these differences are small, it was reported that BMI had stronger association with health risk factor levels [25]. Generally, the limitations of the BMI in the separating the fat mass from the fat free body mass are well known [26]. High BMI is able to identify children with excess body fatness in [27], normal weight children may reflect their BMI or fat mass, lean mass level [4-5].

In a study investigating the relationship between obesity and anthropometric measurements in adolescents, it was reported that BMI was associated with a skinfold thickness fat percentage $(r=.40, p<0.05)$ at a significant level when gender variation was not considered [28]. In addition, several studies have reported a moderate correlation $(\mathrm{r}=0.7)$ between BMI and body fat ratio [24, 6, 29]. BMI is a poor indicator of body fat ratio in children with normal body weight [24].

Though skinfold thickness is a better predictor of body fat ratio than BMI, it was shown that the differences between the two criteria in most studies were relatively low $[4,24,30]$. In girls between 8 and 19 years of age, only triceps skinfold thickness showed strong correlation with the body fat ratio determined by underwater body weight measurement $(r=0.72)$ BMI compared to lower correlation of BMI [31]. Similarly, the body fat ratio obtained with dual energy X-ray absorptiometry was found to be highly correlated with BMI $(r=0.87-0.89)$ and skinfold thickness $(r=0.92-0.93)$ [30]. The accuracy of skinfold thickness measurement in predicting body fat ratio varies depending on the measurement locations selected and the formulations used [4]. Bray et al. reported that four anatomical regions of the skinfold measurements taken for determining the body fat compared to the formula of BMI (respectively R2 $=0.85$ and 0.67 ) was more strong estimator. The subscapular skinfold thickness is strongly 
correlated than the triceps skinfold thickness [24]. Absence to obtain skinfold measurement from the leg region in our study may be a cause of reduced correlation between BMI and TST.

\section{Conclusions}

It can be concluded that the relationship between BMI and TST varies due to age, gender, and habitual physical activity. In short, it is clear that BMI and TST measurements cannot be used alternately in the evaluation of body composition of active and sedentary children aged 8-14.

Further research with large sampling from all provinces of Turkey is required to determine whether BMI and TST can be used interchangeably in the evaluation of body composition in active and sedentary children from different age groups.

\section{REFERENCES}

[1] UNICEF, WHO, World Bank. (2015). Levels and trends in child malnutrition: UNICEF-WHO-World Bank joint child malnutrition estimates. Online available from https://data.unicef.org/wp-content/uploads/2015/12/JME-20 15-edition-Sept-2015 203.pdf

[2] Geiss, H.C., Parhofer, K.G., Schwandt, P., Parameters of childhood obesity and their relationship to cardiovascular risk factors in healthy prepubescent children. Int J Obes; 25:830-7, 2001

[3] Lindsay, R.S., Hanson, R.L., Roumain, J., Ravussin, E., Knowler, W.C., Tataranni, P.A., Body mass index as a measure of adiposity in children and young adults: relationship to adiposity by dual energy X-ray absorptiometry and to cardiovascular risk factors. J Clin Endocrinol Metab; 86:4061-7, 2001.

[4] Freedman, D.S., Katzmarzyk, P.T., Dietz, W.H., Srinivasan, S.R. \& Berenson, G.S., Relation of body mass index and skinfold thicknesses to cardiovascular disease risk factors in children: the Bogalusa Heart Study1-4 Am J Clin Nutr; 90:210-6, 2009.

[5] Demerath, E.W., Schuber, C.M., Maynard M, Sun, S.S., Chumlea, W.C., Pickoff, A. et al., Do changes in body mass index percentile reflect changes in body composition in children? Data from the Fels Longitudinal Study. Pediatrics; 117:e487-95, 2006.

[6] Daniels SR, Khoury PR, Morrison JA., The utility of body mass index as a measure of body fatness in children and adolescents: differences by race and gender. Pediatrics; 99(6):804-7, 1997.

[7] Pietrobelli, A., Faith, M.S., Allison, D.B., Gallagher, D., Chiumello, G., Heymsfield, S.B., Body mass index as a measure of adiposity among children and adolescents: a validation study. J Pediatr; 132:204-10, 1998.
[8] Rolland-Cachera, M.F., Deheeger, M., Bellisle, F., The adiposity rebound and adult obesity. In: Madeiros-Neto G, Halpern A, Bouchard C, editors. Progress in obesity research: 9. Proceedings of the 9th International Congress on Obesity. London: John Libbey Eurotext Ltd; p.456-62, 2003.

[9] Duvigneaud, N., Matton, L., Wijndaele, K., Deriemaeker, P., Lefevre, J., Philippaerts, R. et al., Relationship of obesity with physical activity, aerobic fitness and muscle strength in Flemish adults. J Sports Med Phys Fit;48:201-10, 2008.

[10] Artero, E.G., Espana Romero, V., Ortega, F.B., Jimenez Pavon, D., Ruiz, J.R., Vicente Rodriguez, G, et al., Health related fitness in adolescents: Underweight, and not only overweight, as an influencing factor. The AVENA study. Scand J med Sci Sports; 20:418-27, 2010.

[11] Baxter-Jones, A.D.G., Eisenmann, J.C., Sherar, L.B., Controlling for maturation in pediatric exercise science. Pediatr Exerc Sci 17(1):18-30, 2005.

[12] Hobold, E., Forner Flores, L.J., Brandt, R., Oldemar Mazzardo Junior, O., Miguel de Arruda, M., Peak height velocity in anthropometry and body composition of students. Rev Bras Cineantropom Desempenho Hum, 17(3):309-315, 2017.

[13] WHO. Global strategy on diet, physical activity and health (2013). 2013th ed. Geneva, Switzerland: World Health Organization. Online available from http://www.who.int/di etphysicalactivity/M\&E-2008-web.pdf

[14] Morimoto, A., Nishimura, R., Sano, H., Matsudaira, T., Miyashita, Y., Shirasawa, T, et al., Gender differences in the relatioship between percent body fat and body mass index in Japanese children. Diabetes Res Clin Pract;78:123-5, 2007.

[15] Srdic, B., Obradovic, B., Dimitric, G,, Stokic, E., Babovic, S., Relationship between body mass index and body fat in children: Age and gender differences. Obes Res Clin Pract;6:167-73, 2012

[16] http://researchadvisors.com/tools/SampleSize.htm, 2018.

[17] Barlow, S.E., Expert Committee recommendations regarding the prevention, assessment, and treatment of child and adolescent overweight and obesity: summary report. Pediatrics.; 120(suppl 4):164-92, 2007.

[18] Behnke, A.K. \& Wilmore, J.I., Evaluation of Regulation of Body Built and Composition. Prentice-Hall, Englewood Cliffs, 1974.

[19] Zorba, E. \& Ziyagil, M.A., Body Composition and Measurement Methods. GEN Publishing Office and advertising. Trabzon, Turkey, 1995.

[20] Kirchengast, S., Gender Differences in Body Composition from Childhood to Old Age: An Evolutionary Point of View. J Life Sci, 2(1): 1-10, 2010.

[21] Bukowski, R, Smith, G.C.S., Malone, F.D., Ball, R.H., Nyberg, D.A., Comstock, C.H., Hankins, G.D.V, Berkowitz, R.L., Gross, S.J., Dugoff, L., Craigo, S.D., Timor-Tritsch, I.E., Carr S.R., Wolf, H.M., Alton, M.E., Human sexual size dimorphism in early pregnancy. Am J Epidemiol, 165, 1216-18, 2007.

[22] Wells, J.C.K., Sexual dimorphism in body composition. Best Pract Res Clin Endocrinol Metab, 21: 415-30, 2007. 
[23] Marks, G.C., Habicht, J.P., Mueller, W.H., Reliability, dependability, and precision of anthropometric measurements. The Second National Health and Nutrition Examination Survey 1976-1980. Am J Epidemiol; 130:57887, 1989.

[24] Bray, G.A., DeLany, J.P., Volaufova, J., Harsha, D.W., Champagne, C., Prediction of body fat in 12-y-old African American and white children: evaluation of methods. Am J Clin Nutr. 6:980-90, 2002.

[25] Freedman, D.S., Wang, J., Maynard, L.M. etal., Relation of BMI to fat and fat-free mass among children and adolescents. Int J Obes (Lond); 29:1-8, 2005.

[26] Prentice, A.M. \& Jebb, S.A., Beyond body mass index. Obes Rev;2: 141-7, 2001

[27] Krebs, N.F., Himes, J.H., Jacobson, D., Nicklas, T.A., Guilday, P., Styne, D., Assessment of child and adolescent overweight and obesity. Pediatrics; 120(suppl 4):S193-228, 2007.

[28] Bulduk, E.Ö., Süren, T., Bulduk, S., 10-15 Yaş Grubu Adölesanlarda Antropometrik Ölçümlerin Değerlendirilmes i. Sürekli Tıp Eğitim Dergisi, 2:24, 49-54, 2015.

[29] ] Kerruish, K.P., O’Connor, J., Humphries, I.R. et al., Body composition in adolescents with anorexia nervosa. Am J Clin Nutr; 75:31-7, 2002.

[30] Steinberger, J., Jacobs, D.R., Raatz, S., Moran, A., Hong, C.P., Sinaiko, A.R., Comparison of body fatness measurements by BMI and skinfolds vs dual energy X-ray absorptiometry and their relation to cardiovascular risk factors in adolescents. Int J Obes (Lond); 29:1346-52, 2005.

[31] Himes, J.H., Bouchard, C., Validity of anthropometry in classifying youths as obese. Int J Obes; 13:183-93, 1989. 